\title{
Feasibility Study of Rainwater Harvesting in Public Buildings: A Case Study in Bayraklı, İzmir
}

\author{
Erman Ülker, ${ }^{1, a, *}$ \\ ${ }^{1}$ Faculty of Architecture and Engineering, Civil Engineering, İzmir Kâtip Celebi University, 35620 İzmir, Türkiye \\ ${ }^{*}$ Corresponding author

\begin{tabular}{l|l}
$\begin{array}{l}\text { A R T I C L E I N F O } \\
\text { Research Article }\end{array}$ & $\begin{array}{l}\text { A B S T R A C T } \\
\text { pressures increase day by day, most communities on Earth are facing a shortage of water resources. } \\
\text { For this reason, the authorities started to look for alternative water resources. As a matter of fact, } \\
\text { the harvesting of rainwater has once again gained importance and has been the subject of research } \\
\text { by researchers and engineers. In this study, investigating the rainwater harvesting potential in public } \\
\text { buildings in the Bayrakli district of İmir shows that approximately } 41 \text { thousand tons of rainwater } \\
\text { Accepted : 14/02/2022 } \\
\text { can be harvested, which corresponds to 0.17\% of the population demand. On the other hand, this } \\
\text { rate decreased to 0.15\% in the 2031 projection. We believe that rainwater harvesting in public } \\
\text { buildings in urbanized areas is not sufficient, and that authorities should encourage or finance } \\
\text { communities that install rainwater harvesting systems to avoid further water stress. }\end{array}$
\end{tabular}

Rainwater harvesting

Water stress

Public buildings

Green communities

Feasibility

\section{Introduction}

Water is one of the most essential needs for life. European Union defines as "Water is not commercial product like any other but, rather, a heritage which must be protected, defended and treated as such". Due to growing populations and industries, water demand has been increasing rapidly. Water resources are under strong pressure in terms of both quantity and quality because of the global warming and pollution. Today, the challenge of water security is global and growing day by day. Water is vital for humans, animals and plants. Growing populations and climate change are added burdens to the global water crisis. Water use has been increasing worldwide by about $1 \%$ per year since the 1980s. Global water demand is expected to continue increasing at a similar rate until 2050. Also, Schlosser et al. (2014) stated that approximately $50 \%$ of the projected 9.7 billion human population in the world is expected to have moderately stressful water supply conditions by 2050 .
The total amount of water on Earth is approximately 1.4 billion cubic kilometers. Although $75 \%$ of the Earth is covered by oceans in the form of sea water, only $2.5 \%$ of all water on Earth is freshwater. By the numbers 97.5 percent of the water on Earth is salty. Only $2.5 \%$ of all the water on Earth is freshwater. Less than $1 \%$ of this freshwater is usable and available for ecosystems and humans. $68.6 \%$ of the Earth's freshwater is in the form of ice and permanent snow in mountains. Frozen water is unavailable for consumption or use in agriculture. $\% 30$ of the world freshwater on the underground and hard to access. And as little as $0.3 \%$ of freshwater is effortlessly accessible in lakes and rivers. Brazil, Russia, Canada, Indonesia, China, Columbia, and the United States have most of the Earth's surface freshwater resources.

Developing countries, such as Turkey, often face a greater risk of water stress than developed countries. Today, more than half of the global population reside in urban areas. The uncontrolled increase in population and immigration in cities is a major problem of many 
developing countries. This population increase, which causes unplanned urbanization, makes water supply difficult and creates big problems in the evaluation of wastewater. Therewithal, urbanisation increases risks of flooding when the extension of impervious surfaces augments and accelerates urban run-off in cases of heavy rains. If cities are to adapt to survive, they will need to diversify their planning, going beyond a linear approach focused on service provision alone, while minimizing costs. This will necessitate a much broader assessment of water resources and a resilient system designed to protect against shocks. For these reasons, the importance of the rainwater harvesting system increases. Rainwater harvesting is the capture, diversion, and storage of rainwater for a number of different purposes including landscape irrigation, drinking and domestic use, aquifer recharge, and stormwater abatement. The RWH plays a critical role in solving the world's problem of increased water stress. Rooftop rainwater harvesting (RTRWH) is the most common technique of rainwater harvesting.

The prevalence of RWH systems and the use of rainwater in European countries is varied. In the UK, the storage of rainwater for home use is popular and has a long tradition. In Germany, one third implement project and design solutions, the support programs, grants and subsidies of all new buildings use rainwater for household purposes through local government subsidies. Similarly, Spain has launched a national program of subsidies for RWH in new buildings. Rainwater is collected on the roof of the New York World Trade Center and used to irrigate the surrounding parks. At Frankfurt Airport, rainwater is used for irrigation and toilet flushing. On the other hand, the Marburg Tennis Court in Germany is irrigated with rainwater supplied from outside. At the Überlingen Bommer Car Wash Facility, rainwater is used for car washing. Rainwater is used in toilet cisterns on 14 of the 25 floors at the Berlin Sony-Center. In the United States, thousands of homes are known to have rainwater storage systems. It is known that most of them are used for garden irrigation and plant growing, while $20 \%$ of them are used for drinking water. In the center of the state of Texas, there are more than 400 systems that meet all their needs from rain water. In the city of Austin alone, 6000 storage tanks are installed. Rainwater stored in The Edith Green-Wendel Wyatt Federal Building is used to meet the water needs of WC, irrigation and cooling towers. During one year, 626,544 gallons of rainwater were collected and reused. In winter, rain water meets $85 \%$ of the total water used in the building.

In this study, the issue of integrating rainwater harvesting system into public buildings (school, hospital, mosque, etc.) in Bayraklı district is discussed. In addition, the effect of rainwater collected with this system on meeting the water demands of the district population was examined. Roof areas of public buildings were obtained using the General Directorate of Land Registry and Cadastre (TKGM) website and Yandex Maps.

\section{Materials and Methods}

\section{Methodology}

All public schools, mosques, hospitals and other state institutions in the Bayraklı district of İzmir were examined on the Yandex map in the parcel inquiry application of the General Directorate of Land Registry and Cadastre
(TKGM). Roof areas of all public schools, mosques, hospitals and other government institutions in the Bayrakl district were obtained using the TKGM site. Potential rainwater harvests of all institutions in the district were calculated by using this area information in the relevant formulas. In this study, the collection and storage of rainwater, which should be considered as efficient and sustainable as possible, and the presentation of different solutions depending on the potential of the buildings in the district that are compatible with the rainwater harvesting system are discussed.

\section{Field of Study}

In this study, it was aimed to determine the potential rainwater harvest of Bayraklı district. Roof area information obtained from the TKGM website was used (Figure 1). According to 29 th General Directorate of Meteorology, the average rainfall in İzmir between 1938 and 2020 is 710.5 millimeters. This amount is suitable for integrating a rainwater harvesting system into Bayraklı district. Rainwater collected by the rainwater harvesting system and accumulated in the storage tank can be used for toilet reservoirs, sinks and garden irrigation in schools, hospitals, mosques and other public buildings. It can also be used as drinking water, if necessary, disinfection processes are applied. In this way, economic gains can be achieved for public buildings.

\section{Water Resources in Izmir}

Drinking and utility water of Izmir, which is the third largest city in Turkey and the largest in Western Anatolia, is supplied from underground water resources (deep wells) and surface water resources (dams, spring waters). The drinking water distribution system of 11 districts (Çiğli, Karşıyaka, Bayraklı, Bornova, Konak, Buca, Gaziemir, Karabağlar, Balçova, Narlıdere, Güzelbahçe) that make up the Old İzmir metropolitan area, including Bayraklı, is integrated and not a discrete system. The water obtained from Sarıkız deep wells, Göksu deep wells, Menemen deep wells, Çavuşköy deep wells, Halkapınar deep wells, Pınarbaşı deep wells, Buca and Sarnıç deep wells, Tahtalı Dam, Gördes Dam and Balçova Dam enters the city from different points and merges in the water distribution system. The water produced from these sources is conveyed to the city by transmission lines, and distributed to all regions at 0-50 meters elevation by establishing a balance with Halkapınar $55000 \mathrm{~m}^{3}$ warehouse, Polygon warehouse, Görece Treatment warehouse, Cumhuriyet warehouses.

\section{Precipitation in Izmir}

In İzmir, the rainfall amount shows the greatest variability among the climate elements. Although the annual average amount of precipitation is 710.5 millimeters, depending on the

changes in the general atmosphere circulation, the total precipitation approaches 1000 millimeters in some years and decreases to around $300 \mathrm{~mm}$ in some years. The amount of precipitation throughout the year increases from the second half of October and continues until May.

The months with the highest monthly average precipitation are December, January and February. 


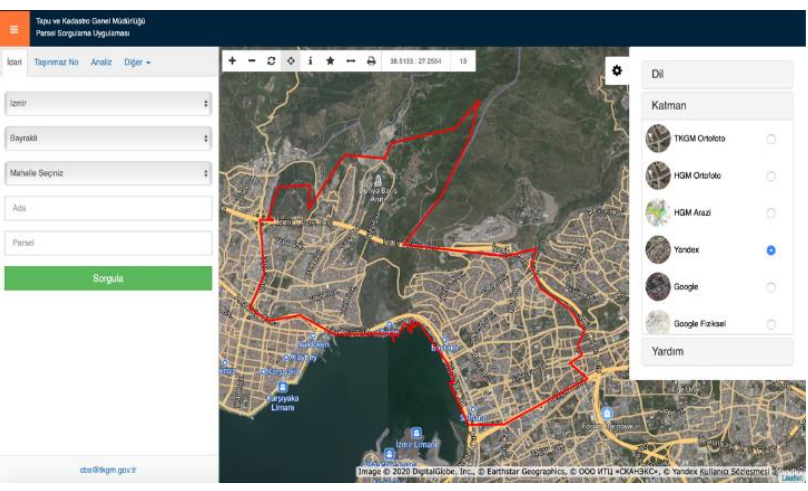

Figure 1. Bayraklı District from the Parcel Inquiry Screen of the TKGM Site

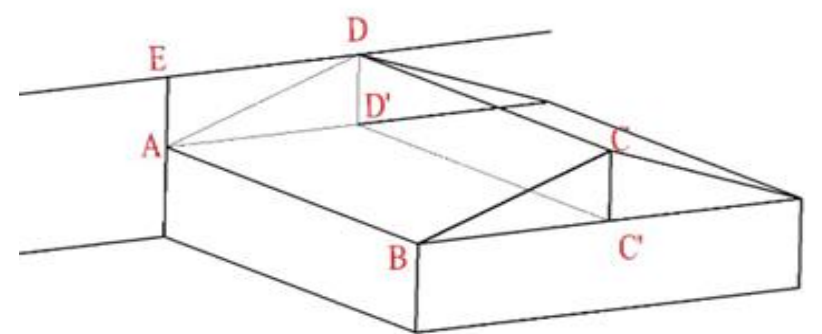

Figure 2. Drawing for Roof Area Calculation

Roof Area (\%) Graph of Public Buildings

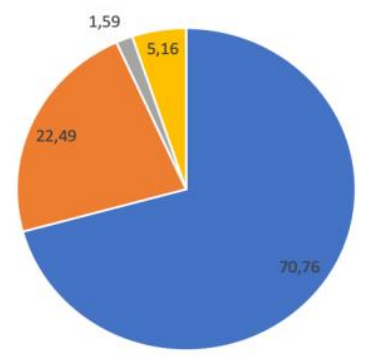

- Schools = Mosques = Hospitals =Other Public Buildings

Figure 3. Roof Area (\%) Graph of Public Buildings

According to the average precipitation values, the annual contribution of precipitation falling only in December is around 20\%. In summer, the share of monthly precipitation in the annual total decreases to $2 \%$.

\section{Roof Shape and Area Calculation}

The harvestable rainwater volume from the roofs of hospitals, mosques, schools and other public buildings in Bayrakl1 district was calculated using the Gould and Nissen formula:

$$
\mathrm{R}=\mathrm{S} \times \mathrm{A} \times \mathrm{Cr}
$$

Where;

$$
\begin{array}{ll}
\mathrm{S}= & \text { Is rainwater harvesting potential } \\
\mathrm{A}= & \text { Is catchment area in } \mathrm{m} 2 \\
\mathrm{R}= & \text { Is monthly rainfall in } \\
\mathrm{mm}, \text { and } \mathrm{Cr}= & \text { Is the runoff coefficient. }
\end{array}
$$

The runoff coefficient depends on the surface type, slope and size of the roofs. The runoff coefficient indicates the proportion of rainwater that can be collected from a roof with certain characteristics and helps calculate the amount of rainwater harvesting. In this study, the roof type is concrete. Therefore, the $\mathrm{Cr}$ value should be taken as 0.70 . Runoff coefficients for common roof types are shown in Table 3. The catchment surface can be determined by collecting the horizontal surface area, half of the vertical height area, and half of the adjacent wall area. Area of $\mathrm{ABCD}=$ roof plan $\mathrm{AB} C^{\prime} D^{\prime}+1 / 2 *$ beveled surface $C D C^{\prime} D^{\prime}+1 / 2 *$ side wall ADE (Figure 2).

\section{Water Demand Calculation}

The annual average precipitation in Turkey is approximately $574 \mathrm{~mm}$, which corresponds to an average of 450 billion cubic meters of water per year. Turkey's technically and economically consumable surface and ground water potential is 112 billion cubic meters per year, of which 54 billion cubic meters is used. According to water availability, countries are classified in three ways as water poor, water scarcity and water rich. Countries are defined as water poor when the amount of usable water per capita per year is less than 1000 cubic meters, water scarce when it is less than 2000 cubic meters, and water rich if it is more than 8,000-10,000 cubic meters. Turkey's annual usable water per capita is around 1,363 cubic meters. According to this data, Turkey is not a water-rich country. According to the annual amount of water per capita, our country is in the position of a country experiencing water scarcity. The Turkish Statistical Institute (TUIK) predicts that the population of Turkey will be 100 million in 2030. In this case, it can be said that the amount of usable water per capita for 2030 will be around 1,120 cubic meters per year. This situation shows that Turkey may be a country with water shortage and water stress in the future.

In this study, the water demand of Bayraklı was calculated according to its population in 2021. While making the calculations, the Bank of Provinces method was used, and the average Daily water consumption per person was taken into account. The population of Bayraklı in 2021 is 306.988. Specific water requirement according to Iller Bank is given in the table 4 .

According to the table, Bayraklı's daily water requirement per person is 225 liters/person/day. According to Iller Bank, daily water demand (D) has been calculated as 69072.3 (ton/day) using the following formula:

$$
\begin{aligned}
& \mathrm{D}=\mathrm{q}_{\mathrm{HY}} \frac{\mathrm{N}}{1000} \\
& \mathrm{P}=100 \sqrt[\mathrm{t}_{\mathrm{e}}-\mathrm{t}_{\mathrm{i}}]{\sqrt{\frac{\mathrm{N}_{\mathrm{i}}}{\mathrm{N}_{\mathrm{e}}}-1}} \\
& \mathrm{~N}_{\mathrm{g}}=\mathrm{N}_{\mathrm{i}}\left[1+\frac{\mathrm{P}}{100}\right]^{\mathrm{t}_{\mathrm{g}}-\mathrm{t}_{\mathrm{i}}}
\end{aligned}
$$

Where;

$$
\begin{array}{ll}
\mathrm{D} & =\text { Is total water demand }\left(\mathrm{m}^{3}\right) \\
q_{H Y} & =\text { Is specific water requirement (L/person/day) } \\
\mathrm{N} & =\text { Is population } \\
\mathrm{t} & =\text { Is time (year) and subscripts e,i,g stands for } \\
& \text { past, current, future time zone, respectively. }
\end{array}
$$

The population of Bayrakl1 in 2031 was calculated as 339105 using the above formula. According to this population, the daily specific water requirement (qHY) will be 225 (L/per/day) in 2031, and daily water demand (D) will be 76298.63 (ton/day) in a day where water is frequently used. 


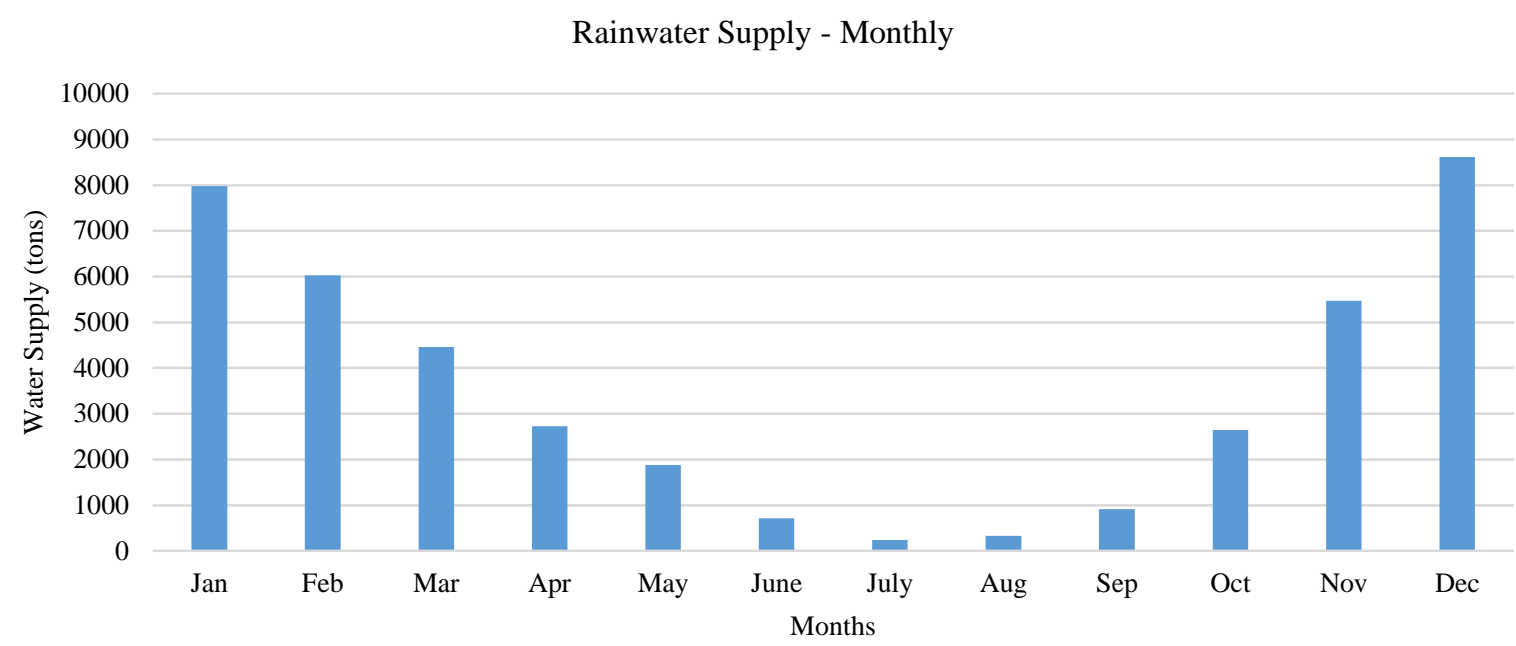

Figure 4. Monthly Rainwater Supply Amounts

Table 1. The Average Monthly Precipitation in İzmir (mm)

\begin{tabular}{c|cccccccccccc}
\hline Months & JAN & FEB & MAR & APR & MAY & JUN & JUL & AUG & SEP & OCT & NOV & DEC \\
\hline Rainfall $(\mathrm{mm})$ & 135.0 & 101.9 & 75.4 & 46.1 & 31.8 & 12.0 & 4.1 & 5.6 & 15.5 & 44.8 & 92.6 & 145.7 \\
\hline
\end{tabular}

Table 2. The Average Monthly Rainy Days in İzmir

\begin{tabular}{c|cccccccccccc}
\hline Months & JAN & FEB & MAR & APR & MAY & JUN & JUL & AUG & SEP & OCT & NOV & DEC \\
\hline Avg. Rainfall Days & 14.0 & 11.7 & 10.7 & 9.1 & 7.0 & 3.5 & 0.7 & 0.9 & 2.7 & 6.6 & 10.1 & 14.4 \\
\hline
\end{tabular}

Table 3. Runoff Coefficients of Common Types of Roofs

\begin{tabular}{l|l}
\hline \multicolumn{1}{c|}{ GI Sheet } & 0.90 \\
\hline Asbestos & 0.80 \\
Tiled & 0.75 \\
Concrete & 0.70 \\
\hline
\end{tabular}

Table 4. Specific Water Requirement per Person $\left(q_{H Y}\right)$

\begin{tabular}{l|c}
\hline \multicolumn{1}{c}{$\mathrm{N}_{\mathrm{n}}$ (person) } & $\mathrm{q}_{\mathrm{H}}(\mathrm{L} /$ day/person $)$ \\
\hline Up to 3000 & 60 \\
$3001-5000$ & 70 \\
$5001-10000$ & 80 \\
$10001-30000$ & 100 \\
$30001-50000$ & 120 \\
$50001-100000$ & 170 \\
$100001-200000$ & 200 \\
$200001-300000$ & 225 \\
\hline
\end{tabular}

Table 5. Monthly Amounts of Harvestable Rainwater

\begin{tabular}{l|cccc}
\hline \multicolumn{1}{c|}{ MR $(1938-2020)$} & $\mathrm{TCA}, \mathrm{m}^{2}(\mathrm{~A})$ & $\mathrm{AMR}, \mathrm{mm}(\mathrm{B})$ & $\mathrm{RC}(\mathrm{C})$ & $\mathrm{RS}, \mathrm{m}^{3}(\mathrm{~A} \times \mathrm{B} \times \mathrm{C})$ \\
\hline January & 84435 & 135.0 & 0.7 & 7979.11 \\
February & 84435 & 101.9 & 0.7 & 6022.75 \\
March & 84435 & 75.4 & 0.7 & 4456.48 \\
April & 84435 & 46.1 & 0.7 & 2724.72 \\
May & 84435 & 31.8 & 0.7 & 1879.52 \\
June & 84435 & 12.0 & 0.7 & 709.25 \\
July & 84435 & 4.1 & 0.7 & 242.33 \\
August & 84435 & 5.6 & 0.7 & 330.99 \\
September & 84435 & 15.5 & 0.7 & 916.12 \\
October & 84435 & 44.8 & 0.7 & 2647.88 \\
November & 84435 & 92.6 & 0.7 & 5473.08 \\
December & 84435 & 145.7 & 0.7 & 8611.53 \\
Annual Rainfall & 84435 & 710.5 & 0.7 & 41993.76 \\
\hline
\end{tabular}

MR: Monthly Rainfall, TCA: Total Catchment Area, AMR: Average Monthly Rainfall, RC: Runoff Coefficient, RS: Rainwater Supply 


\section{Results and Discussion}

In this study, rainwater harvesting potential was calculated based on the total roof area of schools, mosques, hospitals, and other public buildings in Bayraklı, the annual average rainfall of İzmir, and the runoff coefficient according to the roofing material used. Using the parcel inquiry application on the TKGM site, the total roof area of the buildings was determined as 84435 square meters. (Figure 3)

The roofs of almost all of the buildings are made of concrete, so the runoff coefficient is taken into account as 0.7. Annual average precipitation data were obtained from the website of the General Directorate of Meteorology. The results show in both tabular and graphical way in Table 5 and Figure 4.

In this study, information about rainwater harvesting is given. The potential of rainwater to be collected from the roofs of schools, mosques, hospitals and other public buildings with surface area of $84435 \mathrm{~m} 2$ in Bayraklı district to meet the water demands of the region has been investigated. For this purpose, the amount of rainwater to be collected from the roofs was calculated by using the monthly precipitation data of İzmir province. The current population of Bayraklı is 306988. The annual water demand of this population is $25,211,389.5 \mathrm{~m} 3$. The annual amount of rain water that can be collected from schools, mosques, hospitals and other public buildings in the district with the rainwater harvesting system is $41,193.76 \mathrm{~m} 3$. With this system installed in the public buildings in the district, approximately $0.17 \%$ of the annual water demand of the entire Bayrakli population can be met.

According to the calculation made by the Iller Bank method, since the population of the district will be approximately 339,105 in 2031 , the annual water demand of the population will be $27,848,998.13 \mathrm{~m} 3$. With the rainwater collected from the public buildings in the district, $0.15 \%$ of the annual water demand of the population in 2031 will be met. Based on all these calculations, it is concluded that the rainwater collection system is an advantageous system. In today's world where there is a shortage of water and water supply causes great costs, both cheap and practical systems such as rainwater harvesting should be expanded. It is thought that with the dissemination of these systems, the ecological balance will be protected, sustainable development will be ensured and water resources will be used more efficiently.

\section{Conclusion}

Water is a very important resource for humanity and becomes an even more valuable resource as a result of global warming, climate change, waste and population growth. Although more than two-thirds of the world is covered with water, only a small part of it can be used. In addition, a large part of the water is spent and wasted unnecessarily for consumer needs. It is observed that the water need in these regions can be met to a significant extent by rainwater harvesting in some arid and semi-arid regions of the world. Although Turkey is rich in terms of underground and surface water resources, water levels are decreasing gradually as a result of misuse of water. In the coming years, the climate change that will occur as a result of global warming will be felt more and will make the severity of this situation much more important. Rainwater harvesting method, which is not widely used in Turkey, will be effective in solving the problems encountered in arid and semi-arid regions. In this study, it is seen that even when the rainwater harvesting system is placed only in public buildings in Bayraklı district, it meets a substantial portion of the water need in the district. In addition, in order to catch up with the standards applied in the world in rainwater harvesting, especially training; It will be possible to reduce the water shortage in the future by making more efficient use of water by making legal arrangements regarding research and development, investment activities, congresses and rainwater harvesting.

\section{Acknowledgment}

Special thanks to Kubilay Aksakal and Emre Birincioglu for their support in this study to collect rooftop areas in the TKGM website.

\section{References}

Canturk U, Kulaç Ş. 2021. The effects of climate change scenarios on Tilia ssp. in Turkey. Environmental monitoring and assessment, 193(12): 1-15.

Cohen B. 2006. Urbanization in developing countries: Current trends, future projections, and key challenges for sustainability. Technology in society, 28(1-2): 63-80.

Demir T, Mutlu E, Aydın S, Gültepe, N. 2021. Physicochemical water quality of Karabel, Çalt1, and Tohma brooks and blood biochemical parameters of Barbus plebejus fish: assessment of heavy metal concentrations for potential health risks. Environmental monitoring and assessment, 193(11): 1-15.

Ding GKC. 2017. Recycling and reuse of rainwater and stormwater. Encyclopedia of Sustainable Technologies.

Dixon A, Butler D, Fewkes A. 1999. Water saving potential of domestic water reuse systems using greywater and rainwater in combination. Water science and technology, 39(5): 25-32.

Domènech L, Saurí D. 2011. A comparative appraisal of the use of rainwater harvesting in single and multi-family buildings of the Metropolitan Area of Barcelona (Spain): social experience, drinking water savings and economic costs. Journal of Cleaner production, 19(6-7): 598-608.

European Union (EU) Water Framework Directive (WFD) established by the European Parliament and the Council of 23rd of October 2000

Gleick PH. 1993. Water in crisis (Vol. 100). New York: Oxford University Press.

Gould J, Nissen-Petersen E. 1999. Rainwater catchment systems for domestic supply. Intermediate Technology.

General Directorate of State Hydraulic Works Website, Soil Water Resources https://www.dsi.gov.tr/Sayfa/Detay/754

Haq Peng SA. Harvesting Rainwater from Buildings, Springer, Cham; 2017. p. 87.

Kilicoglu C, Cetin M, Aricak B, Sevik H. 2021. Integrating multicriteria decision-making analysis for a GIS-based settlement area in the district of Atakum, Samsun, Turkey. Theor Appl Climatol. 143: 379-388. https://doi.org/ 10.1007/s00704-020-03439-2

Koç İ. 2021. Changes That May Occur in Temperature, Rain, and Climate Types Due to Global Climate Change: The Example of Düzce. Turkish Journal of Agriculture - Food Science and Technology, 9(8): 1545-1554

Koç İ. 2021 The Effect of Global Climate Change on Some Climate Parameters and Climate Types in Bolu. Journal of Bartin Faculty of Forestry, 23(2): 706-719 
Meteorology Website, Seasonal Normals for Provinces 19912020. https://www.mgm.gov.tr/veridegerlenen/il-ve-ilceleristatistik.aspx?m=IZMIR

Mutlu E, Kurnaz A. 2018 Assessment of physicochemical parameters and heavy metal pollution in Çeltek Pond water Indian J. Geo Mar. Sci., 47: 1185-1192

Ozel HB, Cetin M, Sevik H, Varol T, Isik B, Yaman B. 2021. The effects of base station as an electromagnetic radiation source on flower and cone yield and germination percentage in Pinus brutia Ten. Biologia Futura (2021). https://doi.org/ 10.1007/s42977-021-00085-1

Ozel HB, Abo Aisha AES, Cetin M. Sevik H, Zeren Cetin I. 2021. The effects of increased exposure time to UV-B radiation on germination and seedling development of Anatolian black pine seeds. Environ Monit Assess 193: 388. https://doi.org/10.1007/s10661-021-09178-9

Ozel HU, Gemici BT, Gemici E, Ozel HB, Cetin M, Sevik H. 2020. Application of artificial neural networks to predict the heavy metal contamination in the Bartin River. Environmental Science and Pollution Research, 27(34): 42495-42512.

Ozkazanc NK, Ozay E, Ozel HB, Cetin M, Sevik H. 2019. The habitat, ecological life conditions, and usage characteristics of the otter (Lutra lutra L. 1758) in the Balikdami Wildlife Development Area. Environmental Monitoring and Assessment, 191(11): 645 .

Postel S. 2013. Sustaining freshwater and its dependents. In State of the World 2013 (pp. 51-62). Island Press, Washington, DC.

Schuetze, T. 2013. Rainwater harvesting and management-policy and regulations in Germany. Water Science and Technology: Water Supply, 13(2): 376-385.
Schlosser P, Murray MS, Jordan PD, Timmermans ML. 2014. Arctic Change: Integrating Long-Term Perspectives and Current Observations for Understanding Future Impacts and Responses I Posters. In 2014 AGU Fall Meeting. AGU.

Sev A. 2011. A comparative analysis of building environmental assessment tools and suggestions for regional adaptations. Civil Engineering and Environmental Systems, 28(3): 231245.

Tokatli C, Mutlu E, Arslan N. 2021. Assessment of the potentially toxic element contamination in water of Sehriban Stream (Black Sea Region, Turkey) by using statistical and ecological indicators. Water Environment Research.

The United Nations World Water Development Report 2019. Leaving No One Behind

T.C. Ministry of Environment, Urbanization and Climate Change General Directorate of

Varol T, Cetin M, Ozel HB, Sevik H, Zeren Cetin I. 2022. The Effects of Climate Change Scenarios on Carpinus betulus and Carpinus orientalis in Europe. Water Air Soil Pollut 233: 45. https://doi.org/10.1007/s11270-022-05516-w

Varol T, Canturk U, Cetin M, Ozel HB, Sevik H. 2021. Impacts of climate change scenarios on European ash tree (Fraxinus excelsior L.) in Turkey. Forest Ecology and Management, 491: 119199.

Yigit N, Mutevelli Z, Sevik H, Onat SM, Ozel HB, Cetin M, Olgun C. 2021. Identification of Some Fiber Characteristics in Rosa sp. and Nerium oleander L. Wood Grown under Different Ecological Conditions. BioResources, 16(3): 58625874. DOI:10.15376/biores.14.3.7015-7024

Zhai R, Tao F, Lall U, Fu B, Elliott J, Jägermeyr J. 2020. Larger drought and flood hazards and adverse impacts on population and economic productivity under 2.0 than $1.5 \mathrm{C}$ warming. Earth's Future, 8(7): e2019EF001398. 